\title{
IDENTITY POLITICS: WHO CAN COUNT AS INDIGENOUS?
}

\section{N M Nakata}

When I sat down to finally write this article, a televised discussion program, Insight ${ }^{1}$, was running on SBS Australia on the topic of Aboriginal identity. ${ }^{2}$ The audience was almost entirely made up of Aboriginal Australians and the discussions revolved around some very predictable themes and positions:

- who can call themselves Aboriginal;

- what are the criteria of being Aboriginal;

- who has the right to judge and determine who is Aboriginal.

At the heart of this discussion were contentious identity issues largely associated with the ambiguities of people with mixed heritage. These issues emerged around the primacy of colour and of looking recognisably Aboriginal', the significance of Aboriginal cultural values

\footnotetext{
${ }^{1}$ Insight is a national television program on the SBS chanel that caters for the more recent Australian migrants.

http://www.sbs.com.au/insight/episode/overview/490/Aboriginal-or-not ${ }^{2}$ In 2011, there were approximately 550,000 people identified as being of Aboriginal and/or Torres Strait Islander origin, as counted in the Census. This constitutes $2.5 \%$ of the Australian population. Within this Indigenous minority, Torres Strait Islanders are a distinct cultural sub-minority of $6 \%$. Of the approximately 52,000 Islanders, approximately 5000 still reside in the Torres Strait while the rest live in mainland Australia. Historical experiences and discourses of identity vary between these two groups within the common experience of colonisation. The term Indigenous is used in this paper as a shortened inclusive term when discussing issues common to both. http://www.abs.gov.au/ausstats/abs@.nsf/Latestproducts/2075.0Main\%20Features 32011 ? opendocument\&tabname $=$ Summary\&prodno $=2075.0 \&$ issue $=2011 \&$ num $=$ \&view
} 
as an essential basis of Aboriginal identity, questions of whether an individual's life-experience included discrimination and racism, or being treated like an 'Aboriginal' by 'other' Australians, and questions around the links between Aboriginal identity, the distribution of resources, and the perceived relative need for resources.

All of these issues appeared to be anchored in concerns about the official processes required to confirm a person's Aboriginality, according to the official government/community agreed definition, in order to be eligible for positive discrimination measures. In Australia, the official definition includes three criteria, all of which must be satisfied. To be officially confirmed as an Indigenous Australian, an individual must be of Aboriginal or Torres Strait Islander descent, self-identify as such, and be recognised as such in the community in which he or she lives (Gardiner-Garden 2002). People requiring official confirmation must present their credentials to an incorporated Aboriginal or Torres Strait Islander body or organisation, and make their case through the presentations of genealogies and testimonies. If successful, they are presented with a confirmation letter stamped with the common seal of the organisation. This reminds me of the days when we, as Indigenous people, had to present ourselves to government administrators in order to receive our rations of flour, sugar and tobacco.

Those who spoke on the Insight program revealed some of the absurdities and injustices that result from the subjective and arbitrary practices when Aboriginal Australians seek official confirmation of their Aboriginality from Aboriginal organisations charged with that responsibility. These revelations quickly produced more questions that articulated a field of competing grievances and claims to a surviving and continuing Aboriginal identity: 
- Whose histories and experiences most reflected Aboriginal subjection under colonialism and ongoing racial discrimination, and who could still provide the detail and evidence of it?

- Whose historical and contemporary lives most reflected a commitment to maintaining distinct cultural identities, and

- Whose contemporary lives reflected an ongoing commitment to Aboriginal values and other Aboriginal people?

Over the course of the discussions throughout the program, the need to apply the three definitional criteria appeared to be upheld-descent and self-identification seemed to be generally accepted as an incomplete basis for claiming Aboriginal identity. And the downward spiral began. The necessity for some definitional criteria was supported by the implied argument that an individual's Aboriginal heritage needs to be embodied in some demonstrable and verifiable way in order to be officially recognised. Following that basis, the inference was that resources should go to those who had the best claims to being Aboriginal and the most in need of the resources. Then, of course, the priority of needs was contested; in one case, the needs of young children in communities were pitched against those of university students, and in turn whether academic scholarships for Indigenous higher education students could be considered as a need. The extension of identity arguments to a discussion of access to positive discrimination entitlements and/or resources implies that these sentiments also extend to Torres Strait Islanders and are issues for the Australian Indigenous community as a whole.

The discussion tonight on Insight would be familiar to indigenous people in other places as well. It parallels the historical analysis of fellow contributor to this edition, Bronwyn Carlson, and in particular to her doctoral thesis on The Politics of Identity: Who Counts as Aboriginal Today? (2011). However, in these ways of discussing and 
contesting the meaning of being Aboriginal or Indigenous, the 'identification' problem remains, and in the final determination centres on the third criteria of 'acceptance by the community in which one lives'. However, the question that many Indigenous Australians ask in private is: How can others, acting on behalf of a political and cultural collective, make judgement of an individual's claim to an Indigenous identity in the light of diverse Aboriginal historical experiences, the inter-generational mixing of heritages, and the contemporary social and geographical mobility of younger generations? Who is in a position to judge the historical journeys of all those of indigenous descent? In whose eyes, and on whose 'authority' can recognition be accorded fairly? The old relied-upon Indigenous ways of 'knowing each other' through older lines of knowledge and connectedness no longer work as well as they once did for many of us. Unless an individual possesses an acceptable historical narrative and/or works hard at building and maintaining an acceptable community profile, they stand to be assessed as inauthentic, accused of concocting a fraudulent act, and on both these counts, risk being rejected by the community (Carlson 2011).

\section{Questioning the Everyday Community Discourse of Indigenous Identity}

In an Indigenous population that is not just growing but growing younger, increasing numbers of Australian Indigenous families and individuals are becoming removed from direct experience of previous eras of oppression. They are also increasingly growing up in cities away from ancestral lands or the colonial collectives that formed around reserves and missions. These are two critical sources of cultural knowledge and historical experience required to build an officially acceptable identity narrative. As well, many of the victims 
and descendants of the Stolen Generations ${ }^{3}$ are reconnecting. It is not at all surprising then that the notion of community recognition as the basis for acceptance is fraught. Nor is it surprising, given the incomplete history of Aboriginal experiences of government policy, that some Aboriginal experiences and identities are more recognisable and acceptable than others, and some are more easily questioned, dismissed, or excluded than others. For my own group-Torres Strait Islanders-community recognition is a less contentious issue because of our different history. As long as an Islander family name can be retrieved, individuals can still be placed. In what is a small contemporary community, who historically were isolated on their own islands and kept apart from most other Australians as 'Reserves' until the 1960s, living memories are still strong. Nor is adherence to Islander custom stringently judged as an essential basis for identification as it often is in Aboriginal Australia. For Islanders, the emphasis is on family lines as a source of continued belonging and recognition. The passage of time, of course, may well intensify these issues in the Torres Strait Islander community in the way they now affect those Aboriginal people whose lives and kin networks have been disrupted for 230 years.

However, what is surprising, to me at least, is that although the processes for identity confirmation are questioned, the definition of Indigenous identity itself 'flies by us' relatively unquestioned along with the criteria for its determination. This was also found to be the case in Carlson's interview data (2011), and suggests that the contests over 'who is', 'what constitutes', and 'who should benefit from' claims

\footnotetext{
${ }^{3}$ The term Stolen Generations refers to those Indigenous Australians who were taken by White authorities from their mothers and families as children and placed in institutions and White foster or adoptive families (see Wilson, 1997). This occurred over generations as a matter of policy or practice until the 1970s. Many descendants now seek to reconnect and claim these stolen identities.
} 
to an indigenous identity are continually being reproduced through the restricted and embedded ways it is talked about in the broader community. Here I am not absolutely dismissing the need for a definition per se; while there is a political will or need to claim identified resources, whether from public, private or indigenous sources, there will always be official pressure for some form of 'identity check' in the interests of ticking off on transparency, fairness and accountability. And, where there is a will to survive as distinct people who have the longest claim to the land, there will need to be language enough to describe continuity and persistence of distinctiveness in contemporary and future contexts. Nevertheless, I do see a need to draw out the local and national 'community' position that subjects Indigenous individuals to political and moral judgements while authorising some Indigenous narratives of identity that silence and exclude others. This position also accepts that the historically recent pan-Indigenous identity, which has been self-consciously constructed and maintained on 'Indigenous terms', can be reduced to a definable, categorical, universally applicable 'narrative' of who 'we all are' or ought to be.

Compounding these emerging ways of talking and knowing each other is the added problem of a narrowing 'construct' of community itself, a concept that entered the popular discourse in the 1970s to enable the distribution of government funds and resources (PetersLittle 2000). The construct of 'community' as understood in contemporary terms is an inadequate substitute for traditional senses of social relatedness and communal orientations but seems to have been readily accepted by many who live in cities far away from communities as a legitimate equivalent, and a surrogate community. And so, I do question the easy community acceptance of the need for regimes of Indigenous identity confirmation that lead to internally oppressive practices. Such practices continue to diminish us, as they 
once did by government administrators, and abandon the efforts of our forbears who suffered and struggled for better treatment, and sought to be free of the confinements imposed by the so-called 'protection' regimes of early governments and missionaries. "We are in a closed box and wait for the lid to be taken off" (Torres Strait Islander to Deputy Chief Protector in Report 22 February 1936, 3). My objection to these emerging ways of "talking and knowing" who is Indigenous, however, leads me away from the logic that questions how individuals construct and express their Indigenous identities. It also directs me away from restricted narratives and judgements about what it means to be Indigenous. It leads me to think that the lines between debate about what it means to be Indigenous and judgements about whether an individual is Indigenous should be more consciously reflected on, and separated as we all converse and 'discourse' about it at the community level. But, my major concern with the community discourse is in regards to what the preoccupation with questions of collective and individual identity takes away from other critically important Indigenous agendas-namely agendas which impact on the material circumstances and future possibilities for Indigenous people, for example, how to raise the prosperity of all Indigenous people? What do we have to do now to start the process of eliminating poverty from our communities? How can we ensure all Indigenous people have access to the best available education? Where do we want our communities and people to be in fifty years vis-à-vis White occupation of our lands? How do we recover our ancient knowledge systems from White people's archives and reinstate their primacy in our lives? 


\section{Particularising the Historical Roots of Contemporary Australian Indigenous Identity Discourse}

Clearly there is broad community understanding that Indigenous Australians' contemporary objectification of our own ways for naming and describing ourselves, and recognising each other is constructed in resistance to, and survival of, colonial objectifications of us (as a distinct homogenous social category of people who continue to be subjected to repeated injustices). However, in the way we contest what constitutes the markers of contemporary Indigenous identity at the community level, there are few concessions made to the effects of discursive positioning on our re-working of the colonial categories and the application of these re-worked understandings to ourselves. We understand why and what we define ourselves against, and in distinction from all other Australians and their historical and social assumptions about us. But, broadly speaking, at the community level it appears difficult to reveal and articulate how interpretations of the definitional criteria are discursively produced to effectively work in the interests of privileging some Indigenous historical experiences over others, or to recognise or privilege some Indigenous individual's heritage but not others.

In the way Indigenous identity is talked about, the lines of argument do not always recognise their own investments in different and intersecting discursive histories. In our construction of a panIndigenous identity, these investments draw to serve collective political goals and purposes, and in particular, goals or traditions of those local groups who are still traditionally anchored in their daily lives. And they draw to serve the reconstructions of the cultural knowledge of local groups whose traditions were severely disrupted by colonial activity (Tonkinson 1990). In the process, however, the lived subjectivities of the many thousands of Australian Indigenous families 
and individuals all over the country, sit in tension with these objectified forms. The lived subjectivities of Indigenous individuals have been, and continue to be, differently positioned in relation to historical oppression, continuing discrimination, access to cultural knowledge and continuity, degree of social advantage or disadvantage, generational impacts, gender, physical appearance, geographical location, and so on and so forth.

These diversified experiences suggest that there are particularities of Indigenous colonial and social experience that are not commonly shared by all Indigenous Australians. But, the Indigenous political struggle against the nation-state did give rise to a collective panIndigenous identity claim based on a shared cultural heritage and a shared history of oppression, as a way to transcend the multifarious group, family, or individually specific experiences within the broader history (Tonkinson 1990). The common community interpretation and application of the official definition assumes this shared experience but not so much as one with common outcomes across all Indigenous Australian people's experiences. There is a very strong awareness of differences across the pan-Indigenous community. Rather, the common community discourse assumes a united 'all in' commitment to an ongoing shared cultural and political orientation that depends on promoting and sustaining a unitary, essentialised, and imagined ongoing Indigenous subject as the building block of a socially and culturally cohesive, and politically 'solid' and impermeable collective (Rolls 2001).

Within everyday discourse, an individual may be as 'individual' as they like, as long as they publicly subscribe and demonstrate adherence to the 'community', 'political', and 'cultural' scripts and be 'seen' to participate in 'community' activity. For this, all Indigenous Australians must have a recognisable personal narrative and announce 
themselves publicly in particular ways (Carlson 2011). This practice does not support freedom or creative regeneration of a people with converging and increasingly complex histories, nor does it reflect the everyday reality of how people can or cannot conduct their lives. The tacit rules we have come to instate on each other have now become the authorising elements for the close regulation and surveillance of ourselves as individuals who now must live always under threat of public interrogation or exclusion. This all reeks of the colonialism we have strived for decades to rid our lives of. It suggests, to me at least, that in judging an individual's credentials for Indigenous identity claims, the current interpretive/regulative limits of the collective definition must expand to assume the presence of myriad ways in which the cultural heritage and history of oppression have manifested in different groups, families and individual's lives down the generations and through which it can be publically expressed.

However, and definitional issues aside, in the changing context of an increasingly expanding, urban, and 'mixing' Indigenous population, contests about identity are likely to continue, if not intensify as we saw on this SBS show tonight. Arguably, 'we' the Indigenous 'community' require more self-consciousness and self-examination of the way we talk about Indigenous identity rather than confining ourselves to endless contests over what is to constitute its legitimate markers. Here it is important for international readers to understand at least a little of the history of Indigenous identity production in Australia. Apart from being only $2.5 \%$ of the Australian population, the pattern of White 'settlement' and colonial disruption is relevant to contemporary constructions of Aboriginal identity. As Tonkinson (1999) points out, frontier expansion, which began in 1788, continued to the 1960s when the last of the Indigenous people from the Central Desert were brought in to live in a settled community. Although the particularities of hundreds of traditionally diverse groups were homogenised under 
the universal category of 'Aboriginal' by colonists from 1788, the uneven advance of the colonial frontier ensured that over time, groups, families, and individuals were experientially and socially differentiated. This was achieved through the different circumstances and experiences of the frontier, in different states and territories, which were followed by various and changing colonial policies and the variable, often capricious interpretations of those by different Europeans in different places and times (Rowley 1971). In the earlier and more densely settled parts of the country, dispossession, displacement and violence wreaked havoc on Indigenous groups. Ensuing government administration of so-called Aboriginal 'remnants' produced further dispersals, relocations, coalescence and re-organisation of groups of people. In the process, both differential losses and adaptations of cultural practices proceeded, and identities began to articulate not just around original kin networks but to mission and reserve experiences. Frontier and ongoing contact with Europeans ensured the mixing of 'races' across Australia, and in the first half of the twentieth century, government policies intensified a practice of assimilating fair-skinned, European-acculturating families or individuals into White society. The result was further disruption of Aboriginal kin and social relationships, as contact with extended Aboriginal families was made difficult, if not impossible. Further social-differentiation with regard to material and cultural circumstances also resulted. Along with the removal of fair-skinned children from darker Aboriginal mothers and families all over the country, in what has come to be known as the Stolen Generations, disconnection and dispersal of families was a widespread and farreaching practice over generations (Wilson 1997).

While this summary is far from a full account of historical contingencies, perhaps the most salient points of it for the contests that are evident in the contemporary community discourse are the 
historical policies and practices of assimilation. The long-term aim of Australian assimilation policies was the erasure of part-Aboriginal people. Full blood Aboriginal people were understood to be destined for extinction but part-Aboriginal people represented a threat to the purity of the European population in a country that pursued-and driven by the Labour Party from the outset-an assertive, coherent White Australia immigration policy from 1901 until 1972. In this context, part-Aboriginal people were labelled a 'problem' and deemed a 'transitional' category: people who must inevitably become White by adopting the European ethos, and over generations, the colour. It was not until the 1960s that governments conceded that 'full-blood' Aboriginal people would not die out and nor would 'part-Aboriginal' people discard their Aboriginal selves and disappear quietly into the White society (Rowley 1970, 1971).

With the rise of concerted Aboriginal political activism in the 1960s and 70s, and continuing through to the present, the rejection of assimilation was so profound that the concept of 'part-Aboriginality' was also categorically rejected (Coombs 1976). For the last four to five decades, we have come to adopt a very silly proposition that an individual is Aboriginal or an individual is not Aboriginal (e.g., Behrendt 1994). There is no in-between position with which to identify. All the terminology that represented colonial division of Aboriginal people from kin and each other-part Aboriginal, halfcaste, all the blood quantum measures and the more contemporary meaning of hybrid - are soundly rejected. This political move does not in any way overtly exclude those who are now not recognisably Aboriginal people in the physical sense, those whose continuity with cultural practices has been interrupted, or those who have been intergenerationally disconnected and seek to return. The repugnance for the historical division of families according to blood quantum militated against colour being used as a basis for determining identity 
(Anderson 1994, 1997). It also means there is a willingness to take those disconnected from their families back into the fold. However, as a result of historically imposed social divisions and the resultant cultural and kin discontinuities, inclusion into the Indigenous fold does entail conditions which produce the current predicament.

From the 1960s, vocal appeals to a common pan-Indigenous identity have mobilised around ongoing political resistance to our containment within the nation-state. This standpoint does not just mobilise identity as a resource to secure State resources or social justice. It also mobilises around our continuing survival as a distinct people living almost invisibly amongst tens of millions of others. Thus, political assertion is also expressed through the urge for cultural renewal. This urge has placed the logic of dynamic or organic cultural change in a struggle with the logic of cultural essentialism, which is widely mobilised as a strategic political resource (Anderson 2003). However, while 'dual' or 'mixed' heritage is accepted, an individual's primary political and cultural identification must be demonstrably Indigenous.

The political move of the 1960s and 70s to instate simplistic either/or identity choices is increasingly being contested by some in terms of how it demands individuals to deny the fuller, more complex, personal lived expressions of all that they are (Holland 1996, Paradies 2006, Ganter 2008). Indigenous desire for a political pan-Indigenous solidarity, forged from a unity based on a shared cultural heritage and a shared history of oppression, becomes counter-productive and increasingly a site of resistance itself when mobilised to fix individual identities or to impose prescribed ways of enacting cultural and political commitments. It is here that an understanding of discursive positioning helps to reveal that the meanings of Indigeneity cannot be pinned down and fixed in advance of the discourses that produce them. To do so is to provide the conditions for both resistance and the 
ongoing social regulation of Indigenous bodies and Indigenous intellectual thought and speech (d'Cruz 2001, Langton 2003, Paradies 2006). An understanding of discursive positioning reveals how the attempt to pin down Indigenous identity in the collective sense in reaction to the 'positioning' nation-states produces as well our pernicious inter-personal readings of each other as individuals at the local community level.

\section{Expanding the Limits of Australian Indigenous Identity Discourse}

Contests around the objectified meaning of being Indigenous are likely to deepen over time where these depart from lived subjectivities. It is not easy at the community level to understand the discursive conditions of the objectification of Indigenous identities and the implications for those Indigenous subjectivities that do not fit this imagined reality. As someone who grew up as part of an Islander society, in a remote area of Australia, where we were the population 'majority' in the region, I was immersed in customary practice and had no self-consciousness about my identity in cultural terms. I was who I was, and although I recognised my difference from White people, being at home in my own world did not preclude an interest in knowing the outside world nor a desire for separation from it. This is not to say that all Islanders respond this way. I did have a more conscious political sense of myself as part of a long-controlled population still subject to diminishment and humiliation by 'White' authorities. Conversations about secession from Australia or the less radical pursuit of regional autonomy were part of the everyday yarning and yearning to be free of government control. When I moved to the Australian mainland to study, political ideology and the urge to mobilise our cultural accounts as a remedy for our social disadvantage did not sit well at all with my understanding and experience of our political and social struggles. The limits of these 
arguments glared out at me from the pages of texts and the voices of White liberals, Indigenous radicals, and Indigenous ultra-conformists. My attempts to speak back fell largely into a void and isolated me as some sort of 'bad' Islander who could not understand his own oppression and someone who did not suffer from cultural loss. I wasn't a 'bad' or 'good' Islander, I was merely thinking through my own experiences, capacities and interests in my critical engagements with academic propositions. The idea that my intellectual engagements should confirm and conform to either textual or community narratives was something at odds with my own selfunderstanding of life histories as I had experienced them.

In the twenty-four years since I commenced study, these frustrations about the narrow confines that frame Indigenous arguments in many social domains and discussion, have persisted. These narrow and narrowing ways reflect and are reflected in the 'community' discourses of identity. The way we conceptualise and police Indigenous identity in Australia produces its own disabling effects on the way we think and talk about a whole range of social issues. Quite apart from the exclusionary and silencing effects on Indigenous subjects, and apart from the deleterious effects of the political machinations at the community level, our constructs of Indigenous identity also ground a pervasive and pernicious logic that regulates 'who can speak' and 'what can be said or not said' about any Indigenous interest in any domain (d'Cruz 2001, Langton 2011). Those who speak beyond community discourses, as I often do, are often questioned on more than the logic, potential, or worth of their ideas or arguments. To dissent from the established Indigenous consensus is to invite the questioning of one's identity, especially if that identity is ambiguous on any other measure. For instance, while it is difficult to dispute my Australian Indigenous identity, they are not averse to questioning my loyalties to 'culture', 'community', 'the cause', and even at times 
accusing me of 'lacking spirituality'. That is, if you do not have community connections or not living 'your culture' in the community, you can't be accepted as Indigenous. This is a hard pill to swallow when the questions come from people who were not raised in a community rich with traditional languages and practices as I was. I remember these same propositions being expressed in the community long ago, but back then they were expressed by White administrators to divide the community.

It is one thing that the way we talk about Indigenous identity in Australia has come to be the way we talk about and judge each other; this is destructive enough at the personal and community level. But, the larger question is, how does this preoccupation translate at the broader level of social theory, policy and practice? Arguably, it obfuscates, distracts from, and ultimately defers the real work that needs to occur to provide the fullest set of opportunities for Indigenous people. More importantly, more of us should be questioning the tacit acceptance of our narrow assumptions about who we are, as scrutiny of their various deployments will become the first drivers of more constructive agendas. The current trend to position 'identity' as a central organising principle of Indigenous social policy, or frameworks for educational practice ${ }^{4}$ appears logical and has gone unquestioned. It is, however, only logical within its own discourse. If we cannot think what other organising principles might drive social innovations more effectively in Indigenous interests across a range of sectors, we merely illustrate how captive we have become to the discourse-how, for instance, we have almost completely

\footnotetext{
${ }^{4}$ See for instance the Australian Curriculum Assessment and Reporting Authority's Indigenous educational agenda in the proposed national curriculum at ttp://www.australiancurriculum.edu.au/CrossCurriculumPriorities/Aboriginaland-Torres-Strait-Islander-histories-and-cultures
} 
abandoned our early political stance on colonists as squatters on our lands and who need to pay the rent.

To be fair, Indigenous academics and others do consider the effects of our discursive positioning. However, many of these explorations are limited to interrogation of colonial discourses and are largely directed to re-energise our positions against the State or against the dominance of Western concepts and practices (Dodson 1994, Boladeras 2002, Fredericks 2004). There is much less exploration and interrogation of Indigenous discourse and their effects, with some notable exceptions (e.g., Holland 1996, Langton 2003, 2011, Paradies 2006). This also leaves less explored and interrogated limits of our own logic, argumentation and practice in relation to the possible meanings of being Indigenous, and how those limits more insidiously limit wider explorations and ideas to consider the possible ways for Indigenous people to move forward as a collective. Not only are Indigenous individuals ordered and regulated according to these limits, so are the many different ways that individuals reflect, think, analyse, and theorise in and about their social worlds. Thinking that conforms to political and cultural ideologies is unlikely to get us out of the trenches we are so assiduously maintaining. These trenches are home to radically dumb and unadventurous thinking. Not being able to think outside our own favoured ways of thinking about identity is increasingly counterproductive to the Indigenous cause, as some are beginning to question (Sutton 2009). To extend the possibilities for improving Indigenous futures, we need to test and contest our own assumptions as much as those of the State or Western knowledge. And the narrow constructs of Indigenous identity and the practices that police it need more conscious reflection not just in the academic sense but also at the community level. The assumptions that underpin Indigenous community discourse on identity are social constructs forged as part of a larger political rebuttal of the propositions of the 
nation-state, and while culturally and historically informed, they are not sacred or non-negotiable areas, however much the community discourse might imply.

\section{Conclusion}

The dilemma of who can count as Indigenous today emerges in the pernicious ways that it does at community levels because many quite genuinely and seriously believe that boundary policing of 'who is' and 'who isn't' Indigenous is fundamental to our futures as distinct people and to our capacity to achieve social justice. This view reflects a very narrow vision of our possible futures, based on an equally narrow understanding of the diversity of Indigenous people's colonial experience and its socially differentiating effects over generations. The concept of community recognition of Indigenous identity, and its interpretation as a criterion of Indigenous identity in Australia, needs serious questioning. It could perhaps be more easily allowed to fall away as an identity criterion if 'what any Indigenous individual says or thinks' in the public domain was assessed or contested on the logic and content of argument, rather than routinely tied to questions or assessments of their 'identity'.

Deeper engagement with the complexities that constitute our sense of ourselves must surely augment our sense of ourselves as survivors able to continue on, beyond other's representations of our primordial natures and beyond our history of traumatic oppression. Where this might lead cannot be foretold, but the possibilities to make and remake ourselves will still be present. None of this precludes continuing efforts to revitalise cultures and efforts to remember and tell our histories-these practices are not suppressible. But, nor should they restrict how individuals can act and think through their own specific histories, capacities and desires to build their own trajectories 
into the future or to contribute to Indigenous social commentary or theorising.

The younger generations increasingly have access to and interests in the ways that global, national and local histories, contemporary realities, and envisioned futures all converge to shape the possibilities for thinking about what their claims to Indigeneity mean personally and how they might be negotiated in the public arena to uphold Indigenous interests beyond their own. Their conceptual work will be how to rethink and rework the interface between the fluidity and diversity of complex personal identities and the rigidity of the defined identity category of the Indigenous collective. In the meantime, the 'work' of the generation above them must include gathering together a larger picture of the Indigenous Australian's historical position, a larger picture of the diverse effects of colonial and ongoing experience on different individuals, families and groups, and a larger vision of future possibilities. If our ways of talking can encompass a larger and more complex picture, the possibilities for Indigenous identity recognition also enlarge to encompass the reality of Indigenous diversity in contemporary times.

In Australia, as it was presented on the television set tonight, the way the Indigenous community currently converses about identity makes it difficult for increasing numbers of Indigenous individuals to negotiate the tensions between their lived identities and those objectified constructions of Indigenous identity that have shaped both our consciousness and our discourse for the last forty to fifty years. If everyone must construct and tell their story to fit the discourse, to be heard, to be recognised, to justify their claim, not only once but day after day after day, here, there and everywhere, then what does the intercourse fail to capture about the reality of contemporary Indigenous identities? My current engagement with younger 
Indigenous university students signals to me that new and thoughtful ways of thinking and talking about Indigenous identity will emerge and eventually transform the current community consensus. It is my hope that these unhelpful deployments of a monolithic Indigenous 'community' will, though our own teaching, be explored by a more questioning younger generation.

\section{References}

Anderson, I. 'Black Bit, White Bit.' Republica 1 (1994): 113-22. Anderson, I. 'I, the Hybrid: Aborigine: Film and Representation.' Australian Aboriginal Studies 1 (1997): 4-14.

Behrendt, L. 'Aboriginal Urban Identity: Preserving the Spirit, Protecting the Traditional in Non-traditional Settings.' The Australian Feminist Law Journal 4 (1994): 55-61.

Boladeras, J. 'It's Easier to be Black if You're Black: Issues of Aboriginality for Fair-Complexioned Nyungar People.' Unpublished Masters Thesis, Curtin University of Technology, Australia, 2002.

Carlson, B. 'The Politics of Identity: Who Counts as Aboriginal Today?' Unpublished PhD Thesis, University of New South Wales, 2011.

Coombs, H.C. 'Aboriginal Australians 1967-1976.' Presented at the Sir Walter Murdoch Memorial Lecture, Murdoch University, 1976.

http://www.murdoch.edu.au/vco/secretariat/records/murdoc hlectures/MurdochLecture1976.pdf

D'Cruz, C. 'What Matter Who's Speaking?' Authenticity and Identity in Discourses of Aboriginality in Australia.' Jouvert: A Journal of Postcolonial Studies 5 no. 3 (2001). Accessed November 13 2012. http://english.chass.ncsu.edu/jouvert/v5i3/cdcr.htm 
Dodson, M. 'The End in the Beginning: Re(de)finding Aboriginality.' In Blacklines: Contemporary Critical Writings by Indigenous Australians, edited by M. Grossman, 25-42. Carlton: Melbourne University Press, 2003.

Fredericks, B. 'Urban identity' Eureka Street, December, 2004.

Ganter, R. 'Turning Aboriginal - Historical Bents.' Borderlands ejournal 7, no. 2 (2008): 1-19. Accessed November 132012. www.borderlands.net.au/vol7no2_2008/ganter_turning.pdf. Gardiner-Garden, J. 2002-2003. Defining Aboriginality in Australia, Department of Parliamentary Library, Canberra, http://www.aph.gov.au/library/pubs/CIB/200203/03cib10.pdf

Holland, W. 'Mis/taken Identity."]' In The Teeth are Smiling: The Persistence of Racism in Multicultural Australia, edited by E. Vasta, \& S. Castles, 97-111. St. Leonards: Allen \& Unwin, 1996.

Langton, M. 'Aboriginal Art and Film: The Politics of Representation.' In Blacklines: Contemporary Critical Writings by Indigenous Australians, edited by M. Grossman, 109-124. Carlton: Melbourne University Press, 2003.

Langton, M. 'Anthropology, Politics and the Changing World of Aboriginal Australians'. Anthropological Forum 21, no. 1 (2011): 1-22.

Paradies, Y. C. 'Beyond Black and White: Essentialism, Hybridity and Indigeneity.' Journal of Sociology 42, no. 4 (2006): 355-367.

Peters-Little, F. 'The Community Game: Aboriginal Self-definition at the Local Level', Research discussion paper no. 10, Australian Institute of Aboriginal and Torres Strait Islander Studies, 2000.

http://www.aiatsis.gov.au/_data/assets/pdf_file/5579/DP10.p df 
Rowley, C. D. The Destruction of Aboriginal Society: Aboriginal Policy and Practice Volume 1. Canberra: Australian National University Press, 1970.

Rowley, C. D. Outcasts in White Australia: Aboriginal Policy and Practice Volume 2. Canberra: Australian National University Press, 1971.

Sutton, P. The Politics of Suffering: Indigenous Australia and the End of the Liberal Consensus. Carlton: Melbourne University Press, 2009.

Tonkinson, M. 'Is it in the Blood? Australian Aboriginal identity.' In Cultural Identity and Ethnicity in the Pacific, edited by J. Linekin and L. Poyer, 191-218. Honolulu: University of Hawaii Press, USA, 1990.

Tonkinson, R. 'The Pragmatics and Politics of Aboriginal Tradition and Identity in Australia.' Journal de la Sociétié des Océanistes 109, no. 2 (1999): 133-147.

Wilson, S. R. 'Bringing them Home.', Report of the National Inquiry into the Separation of Aboriginal and Torres Strait Islander Children from their Families, Human Rights and Equal Opportunity Commission, Canberra, 1997. 